\title{
Corporate Social Responsibility in Preventing Child Marriage In Indonesia: Systematic Literature Review 2016 - 2021
}

\author{
Elvina Ardelia Laksmi ${ }^{1}$, Rina Herlina Haryanti ${ }^{2}$ \\ Sebelas Maret University, Surakarta 571261 \\ \{elvinalaksmi999@gmail.com\}
}

\begin{abstract}
This article aims to find out how companies' roles in Indonesia are to preventing child marriage. One focus of social responsibility toward society by the company is for children. Even though some companies in Indonesia have provided the CSR program with a focus on children and the existence of APSAI as a company feasibility measurement institution for children, there are many children issues aren't resolved yet. One of them is related to the number of child age marriages is classified as far from the target reduction until 8.74\% in 2024 (PPPA Ministry, 2021). This writing method is using a systematic literature review method from the year 2016 until 2021. The criterion of the company used in this research is the company in Indonesia with a focus on preventing child age marriage. The result showed that company in Indonesia mostly has adjusted the CSR, but its relation to preventing the child age marriage was still low. Based on the explanation above, it can be concluded that the target reduction of child age marriage wouldn't be conducted maximally without the role of Indonesian company CSR at its focus on children and stakeholder's role in it.
\end{abstract}

Keywords: Corporate Social Responsibility, The Marriage Preventing, and Child Age

\section{Introduction}

Corporate Social Responsibility can be interpreted as an action by a corporation or large company in providing its responsibilities in the form of material such as money, equipment, or other gifts to communities, organizations, or individuals in the area where the company operates [1]. The form of CSR that is often applied by companies is one based on the form of Carroll's Pyramid of CSR which divides social responsibility into four forms, namely economic, legal, ethical, and philanthropic responsibilities [2]. One of the focuses of social responsibility to the community by the company is to the younger generation of children. Since a child is born, the growth and development of the child will always be provided with facilities that will support their life. This can then become the company's target in fulfilling corporate social responsibility, especially for children.

In Indonesia, the Association of Indonesian Child Friendly Companies (APSAI) has even been formed to determine the eligibility criteria for companies related to the fulfilment of children's rights and measure the feasibility of companies for children [3]. However, this is not enough to overcome the problem of children in Indonesia, one of which is related to the child marriage rate which is still far from the target of decreasing to $8.74 \%$ in 2024 [4]. Many studies related to corporate social responsibility have been done before. The form of corporate ethical responsibility, Andes, Nuzula, and Worokinasih, prioritizes company values so that they can 
continue to compete [5], a form of responsibility to the wider community Astiti and Astiri [6] state that CSR needs to be developed based on community support, environment, and product.

However, although most companies in Indonesia have implemented CSR programs, not many companies have implemented CSR with a focus on children, especially the prevention of child marriage. Thus, this is still a challenge for companies to realize CSR with a focus on children. Therefore, this study aims to find out more details related to corporate social responsibility or CSR in preventing child marriage in Indonesia. The data used in this research are articles published in the google scholar and Garba Reference Digital (Garuda) publication which discusses the prevention of child marriage through CSR programs from 2016 to 2021 . The data is then analysed using a systematic literature review (SLR). The SLR method is a literature review method that identifies, assesses, and interprets findings on a research topic to answer pre-defined research questions [7].

\section{Theoretical Framework}

\subsection{Systematic Literature Review (SLR)}

Systematic Literature Review is a method for identifying, evaluating and interpreting all available research that is relevant to a particular research question, or topic area, or exciting phenomenon. It can be used to summarize interesting research, find new gaps in specific research topics, and position new research [8].

\subsection{Corporate Social Responsibility (CSR)}

Corporate Social Responsibility is an allocation of corporate resources to improve social welfare that serves as a means to improve relationships with key stakeholders [9]. The main purpose of the CSR program is to increase the value of the company by taking into account the social, economic, and environmental dimensions [10].

2.3. Child Marriage

Child Marriage is a marriage that happened before the child is 18 years old and does not yet have physical, physiological, and psychological maturity to responsible for marriage and children the marriage, as well as legal according to religion and country [11].

\section{Methodology}

\subsection{Object of research}

The object of research is a form of CSR carried out by the company in its focus to prevent child marriage. CSR in its focus on children was chosen as an object for the following reasons:

a. CSR focused on children can be an effort to realize the needs of children's rights

b. CSR focused on children can be a solution to reduce child marriage rates

\subsection{Research Methods:}

\section{Review Method.}

The SLR method is a literature review method that identifies, assesses, and interprets findings on a research topic to answer predetermined research questions. The first step is identifying the need for a systematic literature review. In this step, authors develop a review protocol that will be used and evaluate it. After that is formulate the review question that determined with the review focused. Next is conducting a systematic literature search with search strategy and screening appropriate research articles based on inclusion and exclusion 
criteria. The next step is carried out the quality assessment and collecting data. And the last stap is presenting findings in detail and presented in tables and graphs.

\section{Research Question.}

Research questions are determined to keep the review focused. The RQ was designed with the help of Population, Intervention, Comparison, Outcomes, and Context criteria (PICOC) [14]. Table 1 shows the PICOC structure of the research question

Table 1. Summary of PICOC

\begin{tabular}{cl}
\hline Structure & \multicolumn{1}{c}{ Description } \\
\hline Population & Corporate Social Responsibility \\
Intervention & Preventing child marriage \\
Comparison & $\mathrm{n} / \mathrm{a}$ \\
Outcomes & Understanding what companies that implement of CSR in \\
& preventing child marriage in Indonesia \\
& Understanding the forms of CSR that carried out by companies in \\
& preventing child marriage in Indonesia \\
& Understanding the Stakeholders involved by the company in \\
& conducting CSR related to the prevention of child marriage in \\
& Indonesia \\
& The companies used in this study is companies that implement CSR \\
Context & focusing on children
\end{tabular}

The research questions and motivations addressed by this literature review are shown in Table

2.

Table 2. Research Question (RQ)

\begin{tabular}{rll}
\hline ID & \multicolumn{1}{c}{ Question } & \multicolumn{1}{c}{ Motivation } \\
\hline RQ1 & $\begin{array}{l}\text { What companies that implement of } \\
\text { CSR in preventing child marriage in }\end{array}$ \\
Indonesia? & $\begin{array}{l}\text { Implement of CSR in preventing } \\
\text { child marriage in Indonesia }\end{array}$ \\
RQ2 & $\begin{array}{l}\text { What are the forms of CSR that Identify the forms of CSR that } \\
\text { carried out by companies in carried out by companies in } \\
\text { preventing child marriage in preventing child marriage in }\end{array}$ \\
Indonesia? & $\begin{array}{l}\text { Who are the parties involved by the } \\
\text { Indonesia } \\
\text { company in conducting CSR related } \\
\text { to the prevention of child marriage in } \\
\text { Indonesia? }\end{array}$
\end{tabular}

\section{Search Strategy}

Search strategy is used to obtain the data needed in the research to answer research question. The search process is done by using google chrome with the site addresses https://scholar.google.co.id/ and https://garuda.ristekbrin.go.id/. The keywords used in this study "Corporate Social Responsibility", "The Marriage Preventing", and "Child Age". These keywords obtained 236 articles. 


\section{Inclusion and Exclusion Criteria.}

This stage is carried out to decide whether the data (journal articles) found are suitable for use in SLR research or not. Eligible journal articles are included in the Inclusion Criteria, and unsuitable ones are selected in the Exclusion Criteria. These criteria can be seen in Table 3.

\section{Quality Assessment}

In SLR research, the data found is evaluated based on the following quality assessment criteria questions:

QA1. Are the journal articles Sinta-accredited (S1-S6)?

QA2. Are Journal articles published in 2016 - 2021?

QA3. Do the journal articles mention the companies that implement CSR focusing on children?

QA4. Do the journal articles mention the forms of CSR that carried out by companies in preventing child marriage?

QA5. Do the journal articles mention the parties involved by the company in conducting CSR related to the prevention of child marriage?

Table 3. Inclusion and Exclusion Criteria

\begin{tabular}{cl}
\hline Criteria & \multicolumn{1}{c}{ Description } \\
\hline Inclusion & Research articles published in 2016-2021 \\
& Data are taken from the SINTA accredited journal (S1-S6) \\
& The article contains locations in Indonesia \\
& Articles have keywords related to "Corporate Social \\
& Responsibility", "The Marriage Preventing", and "Child \\
& Age" \\
& Research article with incomplete text \\
Exclusion & Research articles in Thesis/Thesis/Dissertation \\
\hline
\end{tabular}

\section{Data Collection}

Data collection is the stage in which data for research is collected. Data collection in this study is through several stages, such as:

a. Searching for journal article on https://scholar.google.co.id/ and https://garuda.ristekbrin.go.id/ (Garba Rujukan Digital/Garuda)

b. Enter the keywords used to search for journals that match the research object, namely this research refers to the keywords "Corporate Social Responsibility", "The Marriage Preventing", and "Child Age".

c. In Filter by Year select Range, choose the year 2016 - 2021 to determine the source of the year in finding CSR issues in efforts to prevent child marriage. After clicking Filter, it will display the title, year of publication, and the author's name.

d. Storing journal articles that have been collected

\section{Data Analysis}

At this stage, the journal articles that have been collected will be analyzed to get answers from the Research Question (RQ). The journal articles to be analyzed are:

a. Companies that implement of CSR in preventing child marriage in Indonesia (RQ1)

b. The forms of CSR that carried out by companies in preventing child marriage in Indonesia (RQ2)

c. The parties involved by the company in conducting CSR related to the prevention of child marriage in Indonesia (RQ3) 


\section{Result and Discussion}

\subsection{Result of Search Process}

In the result of the search process, the data are grouped by year of publication to see research trends related to the Corporate Social Responsibility in Preventing Child Marriage in Indonesia. The graphs of research trends can be seen in Figure 1.

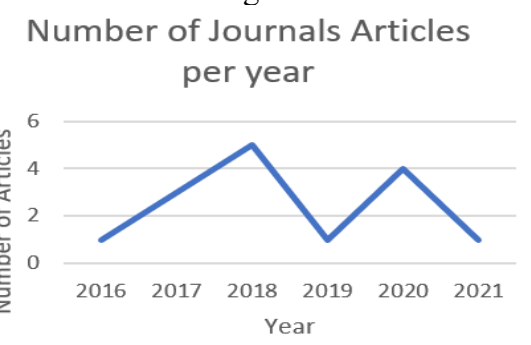

Fig 1. Number of Journal Articles per Year

Mostly journal articles of Corporate Social Responsibility in Preventing Child Marriage in Indonesia were published in 2021 with one article only, and also the minimum of journal article was in 2016 with one article. Journal articles selected based on the Quality Assessment Process. The journal used in this study were all sinta accredited which can be seen in Table 4.

Table 4. Selected Journals

\begin{tabular}{clc}
\hline No & \multicolumn{1}{c}{ Journal } & Sinta Category \\
\hline 1. & Jurnal Penelitian dan Kebudayaan Islam & S5 \\
2. & Jurnal Komunikasi & S4 \\
3. & Jurnal Penelitian Kesejahteraan Sosial & S3 \\
4. & Jurnal Studi Gender dan Anak & $\mathrm{S} 2$ \\
5. & Jurnal Pemberdayaan Masyarakat: Media Pemikiran dan & $\mathrm{S} 2$ \\
& Dakwah Pembangunan & $\mathrm{S} 3$ \\
6. & Share: Social Work Journal & $\mathrm{S} 4$ \\
7. & Jurnal Ilmiah Pekerjaan Sosial & $\mathrm{S} 5$ \\
8. & Jurnal Ilmu Pengetahuan Sosial & $\mathrm{S} 3$ \\
9. & Jurnal Masyarakat Mandiri & $\mathrm{S} 3$ \\
10. & Jurnal Bisnis dan Kewirausahaan & $\mathrm{S} 2$ \\
11. & Jurnal Ilmu Administrasi dan Organisasi & $\mathrm{S} 4$ \\
12. & Jurnal Ilmu Kesejahteraan Sosial & \\
\hline & &
\end{tabular}

\subsection{Result of the Inclusion and Exclusion Criteria}

After the search process, data is selected based on inclusion and exclusion criteria. In this process, 238 journal articles were successfully selected into 15 articles. These results can be seen in Table 5. 


\subsection{Result of Quality Assesment}

Inclusion and exclusion criteria as well as quality assessment resulted in 15 articles. The results of the article must meet the five quality assessment requirements from QA1 to QA5. And if the article does not meet any of the requirements, the journal article is not used. The results of the journal articles that pass the Quality assessment selection can be seen in Table 5 .

Table 5. Result of Quality Assessment

\begin{tabular}{|c|c|c|c|c|c|c|c|}
\hline No & Year & Author & Title & Journal & Sinta & $\begin{array}{l}\text { QA1- } \\
\text { QA5 }\end{array}$ & Result \\
\hline 1. & 2016 & $\begin{array}{l}\text { Astiti, N. P. } \\
\text { Y., \& Saitri, } \\
\text { P. W. [12] }\end{array}$ & $\begin{array}{l}\text { Pengaruh corporate social } \\
\text { responsibility terhadap } \\
\text { kesejahteraan masyarakat } \\
\text { dan citra perusahaan. }\end{array}$ & $\begin{array}{l}\text { Jurnal Bisnis Dan } \\
\text { Kewirausahaan }\end{array}$ & $\mathrm{S} 3$ & Yes & $\mathrm{V}$ \\
\hline 2. & 2017 & $\begin{array}{l}\text { Muhammad, } \\
\text { F. [13] }\end{array}$ & $\begin{array}{l}\text { Pesona Kearifan Lokal } \\
\text { Sebagai Wahana } \\
\text { Peningkatan Produktifitas } \\
\text { Ekonomi Masyarakat. }\end{array}$ & $\begin{array}{l}\text { Jurnal } \\
\text { Pemberdayaan } \\
\text { Masyarakat: } \\
\text { Media Pemikiran } \\
\text { dan Dakwah } \\
\text { Pembangunan }\end{array}$ & $\mathrm{S} 2$ & Yes & V \\
\hline 3. & 2017 & $\begin{array}{l}\text { Qona'ah, S. } \\
{[14]}\end{array}$ & $\begin{array}{l}\text { Implementasi Program } \\
\text { Corporate Social } \\
\text { Responsibility (CSR) PT } \\
\text { Sari Husada Melalui } \\
\text { Pemberdayaan Perempuan } \\
\text { "Warung Anak Sehat" Di } \\
\text { SDN Gondolayu } \\
\text { Yogyakarta. }\end{array}$ & $\begin{array}{l}\text { Jurnal } \\
\text { Komunikasi }\end{array}$ & S4 & Yes & V \\
\hline 4. & 2017 & $\begin{array}{l}\text { Ni'mah, M. } \\
{[15]}\end{array}$ & $\begin{array}{l}\text { Implementasi Kebijakan } \\
\text { Kabupaten Layak Anak di } \\
\text { Kabupaten Probolinggo. }\end{array}$ & $\begin{array}{l}\text { Realita: Jurnal } \\
\text { Penelitian dan } \\
\text { Kebudayaan Islam }\end{array}$ & S5 & Yes & V \\
\hline 5. & 2018 & $\begin{array}{l}\text { Aqiela, L., } \\
\text { Raharjo, S. } \\
\text { T., \& } \\
\text { Resnawaty, } \\
\text { R. [16] }\end{array}$ & $\begin{array}{l}\text { Implementasi Program } \\
\text { Corporate Social } \\
\text { Responsibility (CSR) El- }\end{array}$ & $\begin{array}{l}\text { Corps. Share: } \\
\text { Social Work } \\
\text { Journal }\end{array}$ & $\mathrm{S} 3$ & Yes & V \\
\hline 6. & 2018 & $\begin{array}{l}\text { Marwah, N. } \\
{[17]}\end{array}$ & $\begin{array}{l}\text { Pemberdayaan Masyarakat } \\
\text { Melalui Program Corporate } \\
\text { Social Responsibility } \\
\text { (CSR) Mandiri Bersama } \\
\text { Bank Mandiri di Mrican } \\
\text { Umbulharjo. }\end{array}$ & $\begin{array}{l}\text { Jurnal } \\
\text { Pemberdayaan } \\
\text { Masyarakat: } \\
\text { Media Pemikiran } \\
\text { dan Dakwah } \\
\text { Pembangunan }\end{array}$ & $\mathrm{S} 2$ & Yes & V \\
\hline 7. & 2018 & $\begin{array}{l}\text { Afifah, W. } \\
\text { Mandiri), [18] }\end{array}$ & $\begin{array}{l}\text { Kampanye Pencegahan } \\
\text { Perkawinan Dini } \\
\text { Menggunakan Publik } \\
\text { Space di Taman Bungkul } \\
\text { Kota Surabaya. }\end{array}$ & $\begin{array}{l}\text { JMM (Jurnal } \\
\text { Masyarakat } \\
\text { Mandiri) }\end{array}$ & $\mathrm{S} 3$ & Yes & V \\
\hline 8. & 2018 & $\begin{array}{l}\text { Rusmiyati, } \\
\text { C., \& } \\
\text { Hikmawati, E } \\
{[19]}\end{array}$ & $\begin{array}{l}\text { Program Kampung Ramah } \\
\text { Anak: dari Kampung } \\
\text { Hitam Menuju Layak } \\
\text { Anak. }\end{array}$ & $\begin{array}{l}\text { Jurnal Penelitian } \\
\text { Kesejahteraan } \\
\text { Sosial }\end{array}$ & $\mathrm{S} 3$ & Yes & V \\
\hline
\end{tabular}




\begin{tabular}{|c|c|c|c|c|c|c|}
\hline 9. & 2018 & $\begin{array}{l}\text { Astiti, S. P. } \\
{[20]}\end{array}$ & $\begin{array}{l}\text { Young Mother } \\
\text { Psichopreneur School: } \\
\text { Pendampingan Psikis Dan } \\
\text { Kewirausahaan Ibu Muda } \\
\text { Korban Pernikahan Dini } \\
\text { Berbasis Komunitas } \\
\text { Terintegrasi. }\end{array}$ & $\begin{array}{l}\text { Jurnal Studi } \\
\text { Gender dan Anak }\end{array}$ & S2 & Yes \\
\hline 10 & 2019 & $\begin{array}{l}\text { Perdana, F. R. } \\
{[21]}\end{array}$ & $\begin{array}{l}\text { Pemberdayaan Berbasis } \\
\text { Partisipasi Masyarakat } \\
\text { Melalui Program Kampung } \\
\text { Ramah Anak di Badran } \\
\text { Kota Yogyakarta. }\end{array}$ & $\begin{array}{l}\text { Jurnal } \\
\text { Pemberdayaan } \\
\text { Masyarakat: } \\
\text { Media Pemikiran } \\
\text { dan Dakwah } \\
\text { Pembangunan }\end{array}$ & $\mathrm{S} 2$ & Yes \\
\hline 11. & 2020 & $\begin{array}{l}\text { Indriyani, I. } \\
\text { L., Gokhan, } \\
\text { G., Aditya, } \\
\text { R., Perdana, } \\
\text { G. P., \& } \\
\text { Isnaeni, A. P. } \\
\text { [22] }\end{array}$ & $\begin{array}{l}\text { SEKOLAH } \\
\text { DREAMABLE: Sebuah } \\
\text { Upaya Meningkatkan } \\
\text { Kemandirian Anak } \\
\text { Berkebutuhan Khusus } \\
\text { (Studi Implementasi } \\
\text { Program CSR PT } \\
\text { Pertamina (Persero) Fuel } \\
\text { Terminal Bandung Group). }\end{array}$ & $\begin{array}{l}\text { WELFARE: } \\
\text { Jurnal Ilmu } \\
\text { Kesejahteraan } \\
\text { Sosial }\end{array}$ & S4 & Yes \\
\hline 12. & 2020 & $\begin{array}{l}\text { Andes, S. L., } \\
\text { Nuzula, N. F., } \\
\& \\
\text { Worokinasih, } \\
\text { S. [23] }\end{array}$ & $\begin{array}{l}\text { Competitive Advantage as } \\
\text { Mediating Factor for } \\
\text { Creating Firm Value: A } \\
\text { Literature Review. }\end{array}$ & $\begin{array}{l}\text { BISNIS \& } \\
\text { BIROKRASI: } \\
\text { Jurnal Ilmu } \\
\text { Administrasi dan } \\
\text { Organisasi }\end{array}$ & S2 & Yes \\
\hline 13. & 2020 & $\begin{array}{l}\text { Febiyan, D. } \\
\text { A., Rusmana, } \\
\text { A., \& } \\
\text { Muryanto, Y. } \\
\text { [24] }\end{array}$ & $\begin{array}{l}\text { Efektivitas Program } \\
\text { Corporate Social } \\
\text { Responsibility Pt Timah } \\
\text { Dalam Meningkatkan } \\
\text { Kualitas Pendidikan Anak } \\
\text { Keluarga Miskin Di } \\
\text { Asrama Kelas Beasiswa } \\
\text { Bangka Belitung. }\end{array}$ & $\begin{array}{l}\text { Peksos: Jurnal } \\
\text { Ilmiah Pekerjaan } \\
\text { Sosial }\end{array}$ & S4 & Yes \\
\hline 14. & 2020 & $\begin{array}{l}\text { Humaedi, S., } \\
\text { Wibowo, B., } \\
\text { \& Raharjo, S. } \\
\text { T. [25] }\end{array}$ & $\begin{array}{l}\text { Kelompok Rentan Dan } \\
\text { Kebutuhannya (Sebuah } \\
\text { Kajian Hasil Pemetaan } \\
\text { Sosial Csr Pt Indonesia } \\
\text { Power Upjp Kamojang). }\end{array}$ & $\begin{array}{l}\text { Share: Social } \\
\text { Work Journal }\end{array}$ & S3 & Yes \\
\hline 15. & 2021 & $\begin{array}{l}\text { Ririh, K. R., } \\
\text { Wicaksono, } \\
\text { A., } \\
\text { Berliandaldo, } \\
\text { M., \& Ajie, F. } \\
\text { T [26] }\end{array}$ & $\begin{array}{l}\text { Kajian Efektivitas Program } \\
\text { Corporate Social } \\
\text { Responsibility (Csr): Studi } \\
\text { Kasus Perusahaan } \\
\text { Pembangkit Energi "Y" }\end{array}$ & $\begin{array}{l}\text { J@ti Undip: } \\
\text { Jurnal Teknik } \\
\text { Industri }\end{array}$ & $\mathrm{S} 3$ & Yes \\
\hline
\end{tabular}

\subsection{Result of Data Analysis}

This stage will answer the questions from the Research Question (RQ) and discuss the results in detail. 
The companies that implement of CSR in preventing child marriage in Indonesia

Based on 15 journal articles obtained in the last six years from 2016 to 2021, companies in Indonesia that provide corporate social responsibility to children as an effort to prevent early marriage are dominated by companies that also collaborate with the government. The table of company that implements CSR in preventing child marriage can be seen in Table 6 .

Table 6. Company that implements CSR

\begin{tabular}{cl}
\hline $\begin{array}{c}\text { Article } \\
\text { Code }\end{array}$ & \multicolumn{1}{c}{ Company } \\
\hline 1. & $\begin{array}{l}\text { Hardys Group Denpasar } \\
\text { Non-Governmental Organizations } \\
\text { Government of West Pengandaran }\end{array}$ \\
3. & Sari Husada Ltd. \\
3. & IPMOMI Paiton Ltd. with Probolinggo Regency Government \\
5. & El. Corps company \\
6. & Mandiri Bank \\
7. & Partners of the East Java National Indonesian Women's Coalition \\
8. & Sari Husada Ltd. with KPPA \\
9. & Indonesian Young Entrepreneurs Association (IYEA) with \\
entrepreneurs & Non-Governmental Organization with Badran Government, \\
10. & Yogyakarta \\
11. & Pertamina Ltd. Fuel Terminal Bandung Group \\
12. & Companies in Developing Countries \\
13. & Timah TBK Ltd. \\
14. & Indonesia Power Ltd. IPJP Kamojang \\
15. & Energy generation company \\
\hline
\end{tabular}

The forms of CSR that carried out by companies in preventing child marriage in Indonesia

Based on 15 journal articles obtained in the last six years starting from 2016 to 2021, the form of corporate social responsibility in the effort to prevent child marriage dominates the responsibility in the education sector as many as 11 articles, then followed by the form of social responsibility in the economic sector as many as five articles, then in the philanthropic sector as many as two articles, and in the social sector one article. The diagram of the number of journal articles in each sector can be seen in Figure 2.

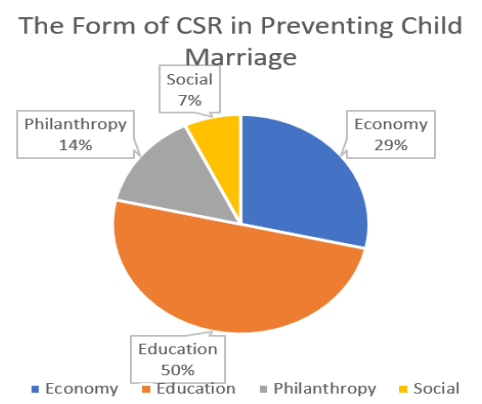

Fig 2. The Form of CSR in Preventing Child Marriage 
The parties involved by the company in conducting CSR related to the prevention of child marriage in Indonesia

Based on 15 journal articles obtained in the last six years, The parties involved by the company in conducting CSR related to the prevention of child marriage in Indonesia are described in Table 7.

Table 7. The parties involved by the company in conducting CSR

\begin{tabular}{|c|c|c|}
\hline $\begin{array}{l}\text { Article } \\
\text { Code }\end{array}$ & $\begin{array}{l}\text { The parties involved by the } \\
\text { company in conducting CSR }\end{array}$ & The Role \\
\hline 1. & $\begin{array}{l}\text { Hardys Group Denpasar, Local } \\
\text { Community, Community }\end{array}$ & Improve Health, Education, and the economy \\
\hline 2. & $\begin{array}{l}\text { Non-Governmental Organizations } \\
\text { with the Regional Government of } \\
\text { West Pengandaran, public } \\
\text { organizations }\end{array}$ & $\begin{array}{l}\text { Managing tourist areas which can improve the } \\
\text { family economy, including the lives of children }\end{array}$ \\
\hline 3. & $\begin{array}{l}\text { Sari Husada Ltd., Faculty of Human } \\
\text { Ecology IPB, and CARE International } \\
\text { Indonesia }\end{array}$ & $\begin{array}{l}\text { Empowering women and children by providing } \\
\text { education }\end{array}$ \\
\hline 4. & $\begin{array}{l}\text { IPMOMI Paiton Ltd. with } \\
\text { Probolinggo Regency Government, } \\
\text { Village Government, Private Sector, } \\
\text { and Community }\end{array}$ & $\begin{array}{l}\text { Providing educational facilities in the form of a } \\
\text { mobile library, student shuttle buses, and } \\
\text { educational seminar workshops }\end{array}$ \\
\hline 5. & $\begin{array}{l}\text { El. Corps company, and local } \\
\text { community }\end{array}$ & $\begin{array}{l}\text { Providing education programs for } \\
\text { underprivileged families, family seminars, and } \\
\text { community involvement in community relations } \\
\text { programs }\end{array}$ \\
\hline 6. & $\begin{array}{l}\text { Mandiri Bank, Giwangan village, } \\
\text { community }\end{array}$ & $\begin{array}{l}\text { Empowerment through "Mandiri bersama } \\
\text { Mandiri", independent education of young } \\
\text { entrepreneurs, and development of public } \\
\text { facilities }\end{array}$ \\
\hline 7. & $\begin{array}{l}\text { Partners of the National Indonesian } \\
\text { Women's Coalition, Surabaya City } \\
\text { Children's Forum, Family Welfare } \\
\text { Empowerment, Surabaya City } \\
\text { Government, Community }\end{array}$ & $\begin{array}{l}\text { Conducting a public campaign to prevent child } \\
\text { marriage and a talk show with the theme "Stop } \\
\text { Child Marriage" }\end{array}$ \\
\hline 8. & $\begin{array}{l}\text { Sari Husada Ltd. with KPPA, task } \\
\text { force, and the local community }\end{array}$ & $\begin{array}{l}\text { Providing economic empowerment and } \\
\text { education through the Community Learning } \\
\text { Activity Centre }\end{array}$ \\
\hline 9. & $\begin{array}{lcr}\text { Indonesian } & \text { Young } & \text { Entrepreneurs } \\
\text { Association } & \text { (IYEA) } & \text { with } \\
\text { entrepreneurs } & & \end{array}$ & $\begin{array}{l}\text { Through the Young Mother Psychopreneur } \\
\text { School program through sharing, business, } \\
\text { marketing, and regeneration activities to } \\
\text { improve the family's economy }\end{array}$ \\
\hline 10. & $\begin{array}{l}\text { Non-Governmental Organization with } \\
\text { Badran Government, Yogyakarta, } \\
\text { Department of Community } \\
\text { Empowerment, Women, and Child } \\
\text { Protection, and Society }\end{array}$ & $\begin{array}{l}\text { Empowerment through the "Child Friendly } \\
\text { Village" program in Badran Village }\end{array}$ \\
\hline 11. & $\begin{array}{l}\text { Pertamina Ltd. Fuel Terminal } \\
\text { Bandung Group, Center for Teaching } \\
\text { and Learning Activities, community }\end{array}$ & $\begin{array}{l}\text { Doing charity by giving books, school supplies } \\
\text { and philanthropy by building educational }\end{array}$ \\
\hline
\end{tabular}


facilities for children and increasing the capacity of teachers

12. Companies in Developing Countries, Public organizations, Local communities Masyarakat

13. Timah TBK Ltd., local government, and community

14. Indonesia Power Ltd. IPJP Kamojang, and Garut Regency Government

15. Energy generation company
Increase company value by optimizing human resources so as to produce a superior and competitive company

Improving the quality of education for children from poor families by providing scholarships

Provide social security. Health and charity

Providing economic empowerment, infrastructure development, charity, and education funds

\section{Conclussion}

Based on the results of the SLR in this study, companies in Indonesia that carry out corporate social responsibility focusing on the needs of children, especially to prevent child marriage, are dominated by local companies in collaboration with local governments. Not many big companies do it independently.

a. The form of corporate social responsibility carried out by Indonesian companies is dominated by the education sector, mainly in the provision of scholarships. This is because education plays a major role in educating a child to become educated and can prevent children from getting married at an early age. In addition, education was chosen as a form of responsibility because in Indonesia itself there are many cases of children dropping out of school due to family economic factors which then cause children to fall into child marriage.

b. Stakeholders or participation in corporate social responsibility activities, which are dominated by the private sector and in collaboration with the government. In addition, the community also plays an important role so that CSR activities can run on a target

\section{Suggestion}

Based on the result of research having been conducted, the authors provide the following suggestions:

a. The results of the assessment with the accreditation of sinta resulted in many journal articles that were not assessed. This causes the journals used to be relatively few compared to the articles found previously. So, the suggestions for further research can eliminate or add journal accreditation criteria in order to get more articles.

b. This study only uses journal articles, so data from other publications cannot be used. So, suggestions for further research can add to the criteria for publication of articles such as theses, theses, or dissertations

c. Because the emphasis is on the form of CSR to prevent child age in Indonesia, the reference must come from Indonesia. For further research, international journals can be used. 


\section{Acknowledgements}

The researcher would like to thank the Faculty of Social and Political Sciences, Sebelas Maret University which has supported and assisted in providing funds to participate in this research and also to Dr. Rina Herlina Haryanti, S.Sos, M.Si. who has guided me in doing this research.

\section{References}

[1] Gantino, R. (2016). Pengaruh corporate social responsibility terhadap kinerja keuangan perusahaan manufaktur yang terdaftar di bursa efek Indonesia periode 2008-2014. Jurnal Dinamika Akuntansi Dan Bisnis, 3(2), 19-32.

[2] Setiawan, T., \& Purwanti, A. (2017). Piramida Carroll Pada Perusahaaan di Indonesia: Studi Pada 3 Perusahaan Pemenang Csr Award 2016. JMB: Jurnal Manajemen dan Bisnis, 6(1).

[3] Yohana, N., Rasyid, A., Lubis, E. E., \& Rimayanti, N. (2019). Communication of Community Participation in Implementation of Policy in Child-Friendly Regency (Kla) in Siak District. International Journal of Research in Social Sciences, 33(1), 2307-227X.

[4] Purnamasari, D. (2021). Kementerian PPPA: Indonesia Targetkan Perkawinan Anak Turun 8,74 Persen pada 2024. URL <https://nasional.kompas.com/read/2021/02/15/12350761/kementerianpppa-indonesia-targetkan-perkawinan-anak-turun-874-persen-pada?page=all $>$

[5] Andes, S. L., Nuzula, N. F., \& Worokinasih, S. (2020). Competitive Advantage as Mediating Factor for Creating Firm Value: A Literature Review. BISNIS \& BIROKRASI: Jurnal Ilmu Administrasi dan Organisasi, 27(1), 5.

[6] Astiti, N. P. Y., \& Saitri, P. W. (2017). Pengaruh corporate social responsibility terhadap kesejahteraan masyarakat dan citra perusahaan. Jurnal Bisnis Dan Kewirausahaan, 12(2 Juli), 94.

[7] Triandini, E., Jayanatha, S., Indrawan, A., Putra, G. W., \& Iswara, B. (2019). Metode Systematic Literature Review untuk Identifikasi Platform dan Metode Pengembangan Sistem Informasi di Indonesia. Indonesian Journal of Information Systems, 1(2), 63-77.

[8] Prastyo, P. H., Sumi, A. S., \& Kusumawardani, S. S. (2020). A Systematic Literature Review of Application Development to Realize Paperless Application in Indonesia: Sectors, Platforms, Impacts, and Challenges. Indonesian Journal of Information Systems, 2(2), 111-129.

[9] Iskandar, I. (2016, June). Pengaruh Penerapan Corporate Social Responsibility terhadap Profitabilitas Perusahaan. In Forum Ekonomi (Vol. 18, No. 1).

[10] Iskandar, I. (2016, June). Pengaruh Penerapan Corporate Social Responsibility terhadap Profitabilitas Perusahaan. In Forum Ekonomi (Vol. 18, No. 1).

[11] Nurhaeni, I. (2016). Perkawinan Usia Anak. Short. Surakarta: FISIP UNS.

[12] Astiti, N. P. Y., \& Saitri, P. W. (2017). Pengaruh corporate social responsibility terhadap kesejahteraan masyarakat dan citra perusahaan. Jurnal Bisnis Dan Kewirausahaan, 12 (2 Juli), 94.

[13] Muhammad, F. (2017). Pesona Kearifan Lokal Sebagai Wahana Peningkatan Produktifitas Ekonomi Masyarakat. Jurnal Pemberdayaan Masyarakat: Media Pemikiran dan Dakwah Pembangunan, 1(2), 275-294.

[14] Qona'ah, S. (2017). Implementasi Program Corporate Social Responsibility (CSR) PT Sari Husada Melalui Pemberdayaan Perempuan "Warung Anak Sehat" Di SDN Gondolayu Yogyakarta. Jurnal Komunikasi, VIII (2).

[15] Ni'mah, M. (2017). Implementasi Kebijakan Kabupaten Layak Anak di Kabupaten Probolinggo. Realita: Jurnal Penelitian dan Kebudayaan Islam, 15(1).

[16] Aqiela, L., Raharjo, S. T., \& Resnawaty, R. (2018). Implementasi Program Corporate Social Responsibility (CSR) El-Corps. Share: Social Work Journal, 8(2), 211-218.

[17] Marwah, N. (2018). Pemberdayaan Masyarakat Melalui Program Corporate Social Responsibility (CSR) Mandiri Bersama Bank Mandiri di Mrican Umbulharjo. Jurnal Pemberdayaan Masyarakat: Media Pemikiran dan Dakwah Pembangunan, 2(1), 113-134.

[18] Afifah, W. (2018). Kampanye Pencegahan Perkawinan Dini Menggunakan Publik Space di Taman Bungkul Kota Surabaya. JMM (Jurnal Masyarakat Mandiri), 189-196. 
[19] Rusmiyati, C., \& Hikmawati, E. (2018). Implementasi Program Kampung Ramah Anak: dari Kampung Hitam Menuju Layak Anak. Jurnal Penelitian Kesejahteraan Sosial, 17(2), 165-178.

[20] Astiti, S. P. (2019). Young Mother Psichopreneur School: Pendampingan Psikis Dan Kewirausahaan Ibu Muda Korban Pernikahan Dini Berbasis Komunitas Terintegrasi. An-Nisa: Jurnal Studi Gender dan Anak, 11(2), 526-536.

[21] Perdana, F. R. (2019). Pemberdayaan Berbasis Partisipasi Masyarakat Melalui Program Kampung Ramah Anak di Badran Kota Yogyakarta. Jurnal Pemberdayaan Masyarakat: Media Pemikiran dan Dakwah Pembangunan, 3(1), 161-188.

[22] Indriyani, I. L., Gokhan, G., Aditya, R., Perdana, G. P., \& Isnaeni, A. P. (2020). SEKOLAH DREAMABLE: Sebuah Upaya Meningkatkan Kemandirian Anak Berkebutuhan Khusus (Studi Implementasi Program CSR PT Pertamina (Persero) Fuel Terminal Bandung Group). WELFARE: Jurnal Ilmu Kesejahteraan Sosial, 9(1).

[23] Andes, S. L., Nuzula, N. F., \& Worokinasih, S. (2020). Competitive Advantage as Mediating Factor for Creating Firm Value: A Literature Review. BISNIS \& BIROKRASI: Jurnal Ilmu Administrasi dan Organisasi, 27(1), 5.

[24] Febiyan, D. A., Rusmana, A., \& Muryanto, Y. (2020). Efektivitas Program Corporate Social Responsibility Pt Timah Dalam Meningkatkan Kualitas Pendidikan Anak Keluarga Miskin Di Asrama Kelas Beasiswa Bangka Belitung. Peksos: Jurnal Ilmiah Pekerjaan Sosial, 19(1).

[25] Humaedi, S., Wibowo, B., \& Raharjo, S. T. (2020). Kelompok Rentan Dan Kebutuhannya (Sebuah Kajian Hasil Pemetaan Sosial CSR PT Indonesia Power UPJP Kamojang). Share: Social Work Journal, 10(1), 61-72.

[26] Ririh, K. R., Wicaksono, A., Berliandaldo, M., \& Ajie, F. T. Kajian Efektivitas Program Corporate Social Responsibility (Csr): Studi Kasus Perusahaan Pembangkit Energi "Y”. J@ ti Undip: Jurnal Teknik Industri, 16(1), 29-41. 